\title{
Viljens frihed og ufrihed i ældre luthersk tradition
}

\author{
Førsteamanuensis cand.theol. ph.d. \\ Peter Olsen, Fjellhaug International University College- \\ Denmark
}

\begin{abstract}
Martin Luther and early Lutheran tradition claimed that God wills both life and death. There is, however, an asymmetry between God's will for life and God's will for death. The article explores how this asymmetry has been handled in different ways within the early Lutheran tradition. Also, the Formula of Concord (1577) understood divine predestination to be the cause of human faith. Later Lutheran Orthodoxy understood human faith to be the reason for divine predestination. In the 1880's these two positions gave rise to a controversy among North American Lutherans. Their main arguments are reproduced. Martin Luther himself believed that everything happened by necessity, but he understood this to be compatible with a distinct version of a free will. In modern philosophical parlance, Luther was a compatibilist. In this, later Lutheran Orthodoxy did not follow the reformer. It moved towards synergism.
\end{abstract}

Keywords: Free will - bound choice - compatibilism - election - predestination - synergism - Martin Luther - Lutheran Orthodoxy

Gud vil både livet og døden. Det er derfor, vi lever, og det er derfor, vi dør. Men Gud vil ikke disse to ting på samme måde. Der er en asymmetri i Guds vilje. Sådan kan man meget kort resumere både Martin Luthers (1483-1546), Philipp Melanchthons (1497-1560) og den lutherske ortodoksis opfattelse af Guds vilje. Men denne asymmetri tilrettelægges ikke på samme måde af alle. Melanchthon forandrer hen over årene den måde, hvorpå han forklarer Guds vilje til liv og Guds vilje til død. Dette gælder liv og død her og nu, og det gælder liv og død i det hinsidige. Den senere lutherske ortodoksi følger Melanchthon i hans ændrede formuleringer, men går et par skridt videre end ham.

De lutherske reformatorer og deres disciple er enige om, at Gud kender fremtiden. Guds forudviden er ikke en prognose, men en faktisk viden. Derfor vil det, som Gud har forudset, med nødvendighed indtræffe. Allerede af den grund sker alting med nødvendighed. Men vi kan desuden finde udsagn både hos Luther, hos den unge Melanchthon og hos flere af teologerne i den tidlige ortodoksi, som 
indebærer, at alting sker med nødvendighed, fordi Gud har bestemt, hvad der skal ske. Martin Luther siger i 1520: "Alting sker med absolut nødvendighed." ${ }^{1}$ Nar det enkelte menneske bliver til, er det, fordi Gud vil det. Han giver os livet. Når det enkelte menneske dør, er det, fordi Gud vil det. Han tager livet tilbage. Undervejs i vores liv sker alle ting, fordi Gud vil det sådan.

Dette tilrettelægges noget anderledes af den ældre Melanchthon og i den senere lutherske ortodoksi. Der forbliver dog en asymmetri i deres formuleringer. Selv de stærkeste formuleringer af Guds vilje og alvirksomhed (pankausalitet), som vi finder hos Luther og hos de tidlige lutheranere, levner plads for menneskets vilje og spontanitet. Ingen af dem argumenterer for det, der er blevet kaldt hård determinisme eller fatalisme. Vi vil se på, hvordan tidlig luthersk tradition har formuleret asymmetrien mellem Guds vilje til liv og Guds vilje til død.

\section{Alle er forudbestemt til frelse}

Sognepræsten i Erfurt, Leonhardt Palhöfer (d. 1566), afviste både synergismen og læren om individuel forudbestemmelse til frelse. $P a ̊ d e n$ ene side gælder det, mente han, at troen skyldes Gud alene. Dette er monergisme. Den menneskelige vilje er ikke en årsag til troen, som synergismen hævder. På den anden side gælder det ifølge Palhöfer, at Guds almindelige frelsesvilje forhindrer, at Han har forudbestemt enkeltpersoner til frelse. Gud har forudbestemt alle mennesker til frelse, siger Palhöfer. Reelt betyder det, at Gud kun har forudbestemt frelsesvejen: Tro på Jesus, så bliver du frelst. Gud har nok forudset, men ikke forudbestemt, hvilke personer der bliver frelst.

Der står dog et logisk problem tilbage: Hvis Gud er alene om at virke menneskers tro, men uden at forudbestemme, hvem der skal tro, hvorfor kommer så nogle og ikke andre til tro (lat. cur alii, alii non)? Men dette spørgsmål må ikke besvares, mente Palhöfer. Vi skal bare fastholde de to linjer, som han fandt i Bibelen: Guddommelig monergisme i omvendelsen og Guds almindelige frelsesvilje. ${ }^{2}$

Palhöfers skrifter om udvælgelsen blev først trykt omkring 30 år efter hans død, hvor de mødte en vis velvilje. I 1593 blev Samuel Huber

1. Assertio omnium articulorum M. Lutheri per bullam Leonis X novissimam damnatorum. WA 7,146,7-8: "Omnia ... de necessitate absoluta eveniunt."

2. Robert Kolb, Bound Choice, Election, and Wittenberg Theological Method from Martin Luther to the Formula of Concord (Grand Rapids, MI/Cambridge, UK: Eerdmans 2005), 179-181. 
(ca. 1547-1624) professor i teologi ved universitetet i Wittenberg. Han var vokset op i Schweiz, men reagerede mod den reformerte lære om forudbestemmelse til både frelse og fortabelse. Dette gjorde Huber med samme påstand som Palhöfer: Gud har forudbestemt alle mennesker til frelse. I virkeligheden har Gud altså kun forudbestemt frelsesvejen (Kolb 2005, 265-266).

Dette var én måde at tilrettelægge asymmetrien på i den tidlige lutherske ortodoksi. Men det var ikke den mest almindelige.

Gud har udvalgt nogle til frelse. Konkordieformlen art. 11

Det lutherske bekendelsesskrift, Konkordieformlen (FC), fra 1577 afviser også synergismen: Det er Gud alene, der bevirker et menneskes tro (FC art. 2,77-78; 87-90). Men i modsætning til Palhöfer og Huber hævder FC art. 11 individuel forudbestemmelse til frelse. ${ }^{3}$ Gud har ikke bare forudbestemt, hvordan man bliver frelst. Han har også forudbestemt, hvilke personer der faktisk bliver frelst. Gud har ikke bare forudset, men forudbestemt disse menneskers frelse. Og disse forudbestemte mennesker vil med sikkerhed blive frelst. Til gengæld afviser bekendelsen individuel forudbestemmelse til fortabelse: Gud har forudset, men ikke forudbestemt, hvem der går fortabt. Det er vigtigt for bekendelsen at skelne mellem Guds forudviden og Guds børns evige udvælgelse til frelse (art. 11 stk. 4).

Bekendelsen siger: Før verdens grundvold blev lagt, har Gud holdt råd, og i sit forsæt har Han bestemt, at Han vil føre netop mig til tro og bevare mig til det evige liv (stk. 45). Denne udvælgelse er individuel, så den gælder ikke alle mennesker, og den er sket for evige tider siden, så den finder $i k k e$ først sted i det øjeblik, en person kommer til tro. Her i tiden effektueres den udvælgelse af enkeltpersoner, som Gud har foretaget før verdens grundvold blev lagt. Gud har ikke bare forudset, hvem der vil tro, men forudbestemmelsen er en årsag til, at de tror (stk. 8). Gud har også forudbestemt, hvornår den enkelte vil komme til tro (stk. 56).

I modsætning til Palhöfer og Huber siger FC altså, at Gud ikke bare har forudbestemt frelsesvejen, men netop de enkeltpersoner, som kommer til tro, og som bliver bevarede i troen indtil det sidste. I modsætning til de reformerte siger FC, at Gud vil alle menneskers

3. Die Bekenntnisschriften der evangelisch-lutherischen Kirche (Göttingen: Vandenhoeck \& Ruprecht 1967), 1063-1091; Konkordieboken. Den evangelisk-lutherske kirkes bekjennelsesskrifter, red. Jens Olav Mæland (Oslo: Lunde 1985), 524-538. Alle henvisninger til FC er til solida declaratio. 
frelse, og at Jesus døde for alle mennesker (stk. 28; 68). Desuden hævder FC i modsætning til de reformerte, at det er muligt for en sandt troende at miste troen (stk. 11; 42). Men FC tilføjer: De forudbestemte vil Gud ikke bare give troen. Han vil også bevare dem i troen, så de faktisk når det evige liv (stk. 22; 32). I modsætning til de reformerte afviser FC, at Gud har forudbestemt nogen til fortabelse. Gud har fra evige tider siden forudbestemt, at den, der ikke tror, skal fortabes. Gud har desuden forudset, hvem der vil gå fortabt, men det enkelte menneskes fortabelse skyldes ikke Guds forudbestemmelse (stk. 4-5; 78). ${ }^{4}$

Asymmetrien i FC's lære om udvælgelsen består altså deri, at Gud har forudbestemt de enkeltpersoner, der vil blive frelst. Derfor bliver disse personer frelst. Men Han har ikke forudbestemt de personer, der vil gå fortabt. Dette gælder på trods af, at der kun er disse to muligheder: Frelse og fortabelse! $!^{5}$ Foruden denne asymmetri finder vi følgende paradoksale formulering i FC: Gud vil ikke, at nogen går fortabt, men at alle skal nå til omvendelse (stk. 81). Alligevel vil Gud straffe dem, som vender sig bort fra Hans hellige bud. Han straffer synd med synd, idet Han forhærder og forblinder mennesker (stk. 83). 6

\section{Tidlig ortodoksi. Johann Gerhard}

Den sidstnævnte paradoksale formulering af Guds vilje genfinder vi mere udfoldet hos professor i Jena, Johann Gerhard (1582-1637). I sit hovedværk Loci Theologici (1610-22) skelner han mellem Guds egentlige eller forudgående vilje (lat. voluntas antecedens) og Guds afledte vilje (lat. voluntas consequens). ${ }^{7}$ Ligesom en god jordisk dom-

4. Robert Preus, "Predestination and Election. Article XI. The Formula of Concord", A Contemporary Look at the Formula of Concord, red. Robert D. Preus \& Wilbert H. Rosin (St. Louis, MO: Concordia 1978), 274; Kolb (2005), 259.

5. Rune Söderlund taler om en brudt forudbestemmelseslære og siger, at "die 'gebrochene' Prädestinationslehre in geringerem Grade rationalisierend ist als der doppelte", Rune Söderlund, Ex praevisa fide. Zum Verständnis der Prädestinationslehre in der lutherischen Orthodoxie (Hannover: Lutherisches Verlagshaus 1983), 28.

6. Bekenntnisschriften (1967), 1086-1087: "Non enim vult Deus quenquam perire, sed potius, ut omnes poenitentiam agant" (stk. 81). "Ut enim haec voluntas Dei revelata est ... Quod eos, qui sponte sese a sancto Dei mandato avertunt ... severissime punire velit" (stk. 83).

7. Ioannis Gerhardi, Loci Theologici, red. Ed. Preuss (Berolini: Gust. Schlawitz 1863 ) tom. 2, loc. 7, cap. 4, \$78: "Ex hoc fonte promanavit distinctio inter voluntatem Dei antecedentem et consequentem"; Johann Gerhard, On Creation and 
mer kun vil det bedste for alle mennesker, men samtidig vil straffe forbryderen, sådan vil Gud det evige liv for alle mennesker, men samtidig vil Han den ubodfærdige synders evige død. Den første vilje er Guds egentlige og oprindelige vilje. Den anden er Guds afledte vilje. Havde det ikke været for synden, havde Gud ikke villet nogens død. Denne sondring mellem to niveauer i Guds viljesliv er ikke i egentlig forstand udtryk for to viljer i Gud, understreger Gerhard. ${ }^{8}$ Selv om begreberne antecedens og consequens ikke forklarer alt, hjælper de os dog med at holde balancen mellem Guds barmhjertighed og Guds retfærdighed, tilføjer Gerhard (cap. 4, \$79).

Ved hjælp af disse begreber kan vi både sige: Gud vil ingen synders død og Gud vil synderens død. Gerhard siger om liv og død her i tiden: "For ethvert menneske har Gud bestemt både timen hvornår og måden hvorpå vedkommende dør. Men Han har ikke gjort det med et absolut dekret, der udelukker alle sekundære årsager." ${ }^{9}$ Gud både vil og bevirker ethvert menneskes død på det tidspunkt og på den måde, som Han på forhånd har bestemt. Dette gør Gud som primær årsag, men Han gør det som regel ved hjælp af sekundære årsager som ulykker, sygdomme, mennesker og djævle.

Vi kan tilføje: Gud vil ikke nogen synders evige fortabelse, og Gud vil synderens evige fortabelse. Ja, Gud bevirker endda denne fortabelse; nemlig som straf for synden. Dette er måske nok paradoksalt, men det er ikke en selvmodsigelse. Det første vil Gud antecedenter. Det andet vil Gud consequenter. Hvis man på dette grundlag vil tale om to viljer i Gud, må man tilføje: Den første vilje er den oprindelige og egentlige. Den er ikke begrundet i noget udenfor Gud. Før syndefaldet stod Adam og Eva kun overfor den guddommelige vilje til liv. Den anden vilje er reaktiv. Den er forårsaget af noget udenfor Gud; nemlig synden. Efter syndefaldet står mennesker overfor begge disse viljer. Nu vil Gud både livet og døden. Han mener både frelsen og dommen helt alvorligt! Men der er en asymmetri i Guds to måder at forholde sig til mennesker på.

Predestination. Theological Commonplaces VIII-XI, red. Benjamin T.G. Mayes \& Joshua J. Hayes (Saint Louis, MO: Concordia 2013), 152.

8. Konkordieformlen art. 11 stk. $35 \mathrm{og} 40$ har en tilsvarende afvisning af to viljer i Gud, på trods af at stk. 81 og 83 netop hævder to viljer i Gud - omend i en anden forstand.

9. Gerhardi (1863) tom. 2, loc. 6, cap. 8, \$79: "Horam et genus mortis unicuique DEUS constituit, non tamen absolute et causas secundas omnes excludente decreto"; Gerhard (2013), 76. 
Johann Gerhard har hentet begreberne voluntas antecedens og consequens fra traditionen. De findes bl.a. hos Thomas Aquinas (ca.122574) i hans Summa Theologica. ${ }^{10}$

\section{Den senere lutherske ortodoksi}

Den senere lutherske ortodoksi forlod Konkordieformlens asymmetriske formuleringer. ${ }^{11}$ I stedet identificerede man Guds forudviden og Guds forudbestemmelse, men på en ganske bestemt måde. I modsætning til Palhöfer og Huber er forudbestemmelsen til frelse individuel, men Gud forudbestemmer de enkeltpersoner til frelse, som Han har forudset vil tro på Jesus. Forudbestemmelsen sker "ud fra forudset tro" (lat. ex praevisa fide) eller "i betragtning af troen" (lat. intuitu fidei). ${ }^{12}$ De troende er ikke forudbestemt til at tro, men de er forudbestemt, fordi de tror. De skylder ikke forudbestemmelsen deres tro, men de skylder troen deres forudbestemmelse.

Typisk ønsker lutherske repræsentanter for denne opfattelse at afvise synergismen. De hævder fortsat, at det er Gud alene, der virker troen i et menneske. De ønsker at være monergister. De vil fortsat hævde en asymmetri. De placerer den bare et andet sted end Konkordieformlen. Det er ikke en asymmetri i forudbestemmelsen. Bekendelsen skelner mellem Guds forudviden og Guds forubestemmelse, og den hævder individuel forudbestemmelse til frelse. De senere ortodokse lægger Guds forudviden til grund for Hans forudbestemmelse. Man kan spørge, om de ikke derved indfører en rationel symmetri, der ophæver monergismen?

Robert Preus (1924-95) konkluderer: "This involves the later Lutheran teachers in a sort of Calvinistic error ... of including election and reprobation as species under a common genus, namely the

10. Thomas Aquinas, Summa Theologica 1, q.19, a.6. Både Gerhard og Thomas henviser for dette vokabular til Damasceneren. Gerhard henviser desuden til Chrysostomus, Anselm og Bonaventura.

11. Den senere lutherske ortodoksi betegner her, at tendensen til synergisme bliver stadigt tydeligere fra Johannes Musaeus (1613-81) til David Hollazius (1648-1713) og især i dele af pietismen. Udviklingen kan følges i brugen og betydningen af udtryk som ex praevisa fide og intuitu fidei (se artiklens behandling af disse udtryk). Om den ældre litteratur, se Söderlund (1983), 80-89.

12. Robert Preus, "The Doctrine of Election as Taught by the Seventeenth Century Lutheran Dogmaticians", Theologische Quartalschrift (senere: Wisconsin Lutheran Quarterly) 55 (1958), 229-261. Hér henvises til paginering i webudgaven http://www.wlsessays.net/bitstream/handle/123456789/4097/PreusElection. pdf?sequence=1\&isAllowed=y (besøgt 26.10.17). Se også Söderlund (1983), 65ff. 
voluntas consequens" (Preus 1958, 12). Ortodoks calvinisme placerer netop både udvælgelsen og forkastelsen under én og samme genus, men hos dem er det Guds voluntas antecedens. Gud har ifølge ortodoks calvinisme både temporalt og logisk før alle tider og før alle menneskelige gerninger forudbestemt nogle mennesker til frelse og andre mennesker til fortabelse. ${ }^{13}$ De senere ortodokse lutheranere er ikke calvinister, men ligesom calvinisterne placerer de både udvælgelse og forkastelse under én genus. Selv om Konkordieformlen ikke brugte disse thomistiske begreber, kan man sige, at den reelt placerer udvælgelsen til frelse under Guds voluntas antecedens og forkastelsen under Guds voluntas consequens. Sagt på en anden måde: Gud vil liv og frelse uden at finde noget hos det enkelte menneske, der begrunder denne vilje. Gud vil død og fortabelse, fordi Han finder noget i det enkelte menneske, der begrunder denne vilje.

Jeg ved ikke, om følgende udtryk blev brugt i den senere lutherske ortodoksi, men de kunne have sagt, at de fortabte blev forudbestemt til fortabelse "ud fra forudset vantro" (lat. ex praevisa incredulitate). ${ }^{14}$ Guds forudbestemmelse bevirker jo ikke tro og vantro, men konstaterer bare på forhånd tro og vantro hos forskellige mennesker, siger de sene lutheranere. I begge tilfælde reagerer Gud på det, som Han forefinder hos mennesket. Det er Guds voluntas consequens, der begrunder både frelse og fortabelse. Gud ved på forhånd, hvem der vil afvise troen, og da Hans forudbestemmelse af enkeltpersoners evige skæbne ikke er andet end forudviden om den, er udtrykkene ex praevisa fide og ex praevisa incredulitate parallelle.

Det skal så tilføjes, at udtrykket "i betragtning af troen" (lat. intuitu fidei) kan forstås på to måder. Robert Preus forklarer: "It can mean simply that faith is included by God as part of the order by which He will bring to completion His election of grace. It can also mean - and this is the meaning which gradually gains preeminence - that faith as it embraces Christ is a factor in God's determination to save some." ${ }^{15} \mathrm{Da}$ de tidlige lutheranere begyndte at bruge dette udtryk,

13. Her er der dog uenighed blandt calvinister om supralapsarisk eller infralapsarisk forudbestemmelse; se Robert Kolb \& Carl R. Trueman, Between Wittenberg and Geneva. Lutheran and Reformed Theology in Conversation (Grand Rapids, MI: Baker Academic 2017), 109 (e-bog); Joel R. Beeke, Debated Issues in Sovereign Predestination. Early Lutheran Predestination, Calvinian Reprobation, and Variations in Genevan Lapsarianism, RHT 42 (Göttingen: Vandenhoeck \& Ruprecht 2017), $165-173$.

14. Udtrykket "intuitu incredulitatis finalis" kendes fra den lutherske skolastik ifølge Richard A. Muller, Dictionary of Latin and Greek Theological Terms. Drawn Principally from Protestant Scholastic Theology (Grand Rapids, MI: Baker 1985), 159160.

15. Preus (1958), 13; cf. Kolb \& Trueman (2017), 101-103 (e-bog). 
var hensigten formentlig blot det førstnævnte, men betydningen gled hurtigt i retning af det sidstnævnte. Det blev stadigt mere en tendens til synergisme.

Med udtrykket “i betragtning af troen” ville teologerne ifølge Robert Preus modvirke Samuel Hubers teologi. Han mente som nævnt, at forudbestemmelsen var kollektiv: Gud har forudbestemt alle mennesker til frelse. Dertil svarede de ortodokse lutheranere: Nej, Gud har forudbestemt dem, der faktisk bliver frelst. De er forudbestemt til at høre evangeliet, komme til tro og bevare troen til det sidste. De er altså forudbestemt til at blive frelst af tro. Og så langt er udtrykket intuitu fidei i overensstemmelse med Konkordieformlen. Men, som Preus tilføjer, synergismen er en naturlig konsekvens af dette udtryk, og i hvert fald rektor for domgymnasiet i Kolberg, David Hollazius (1648-1713), endte i egentlig synergisme. ${ }^{16}$ Hollazius spørger, hvorfor Gud ikke giver alle mennesker troen, og han finder svaret deri, at ikke alle mennesker modstår Helligånden med samme intensitet. ${ }^{17}$ Det naturlige menneske har altså ifølge Hollazius en evne til at begrænse sin modstand mod Gud. Nogle mennesker bruger denne evne, og det er en medvirkende årsag til, at de kommer til tro.

\section{Den nordamerikanske strid om nådevalget}

Blandt de lutherske i Nordamerika udspandt der sig i 1880'erne en langvarig strid om Guds evige nådevalg (ty. die Gnadenwahlstreit). Striden kom hurtigt til at handle om udtrykkene "ud fra forudset tro" og "i betragtning af troen". ${ }^{18}$ Repræsentanter fra især Norwegian

16. Preus (1958), 14: "Synergism is incipient in the phrase ... Plain synergism actually came out in Hollaz." Udtrykket 'egentlig synergisme' (plain synergism) bruges her som forskellig fra den latente eller spirende synergisme (incipient synergism), der ligger i selve udtrykkene ex praevisa fide og intuitu fidei.

17. Robert Preus, "The Influence of the Formula of Concord on the Later Lutheran Orthodoxy", Discord, Dialogue, and Concord. Studies in the Lutheran Reformation's Formula of Concord, red. Lewis W. Spitz \& Wenzel Lohff (Philadelphia: Fortress 1977), 91: "Later theologians tend to depart from the theology of the Formula of Concord on the matter of the freedom of the will ... synergism definitely crops up. Hollaz, for instance, poses the question why God does not grant all men saving faith, and finds the answer in the theory that all unregenerated men do not resist the work of the Holy Spirit with the same intensity." Preus henviser til David Hollazius, Examen Theologicum Acroamaticum (Rostock/Leipzig 1718), 602.

18. Peter J. Thuesen, Predestination. The American Career of a Contentious Doctrine (Oxford/New York: Oxford University Press 2009), 153-168; Söderlund (1983), 153-174; John M. Brenner, The Election Controversy Among Lutherans in the Twentieth Century. An Examination of the Underlying Problems. Ph.D. Dissertation (Mar- 
Synod og fra Ohio Synod ${ }^{19}$ mente, at Konkordieformlen lærte forudbestemmelse til frelse ud fra forudset tro. I 1884 skrev Friedrich August Schmidt (1837-1928) en artikel med titlen Intuitu fidei. Han hævdede: "Our fathers taught ... that God, in eternity, was constrained to see and inquire beforehand what each individual called would do in time and how he would conduct himself, in order to preordain in His eternal purpose, according to His foreknowledge, who among the called should be the elect. And thus it was that many were called, but few chosen" (cf. Matt 22,14). ${ }^{20}$ Schmidt mente, at "troens analogi" (Rom 12,6) betød, at man skulle inddrage andre lærepunkter - først og fremmest retfærdiggørelseslæren - til opklaring af vanskelige passager i Bibelen. Det ene lærepunkt skal bruges til at forhindre, at det andet lærepunkt ender i absurditeter. Da vi retfærdiggøres af tro, kan man konkludere tilbage: Gud foretog den evige udvælgelse, idet Han betragtede troen, hævdede Schmidt. ${ }^{21}$ Når Schmidts modstandere skelnede mellem Guds egentlige vilje og Guds afledte vilje, var der tale om en åbenlys selvmodsigelse, mente han. ${ }^{22}$

Repræsentanter fra især Missouri Synod og Wisconsin Synod afviste Schmidts læsning af Bibelen og af Konkordieformlen, men de erkendte, at en del senere lutheranere havde lært forudbestemmelse ud fra forudset tro. For at modvirke denne misforståelse af Bibelen og bekendelsen formulerede professor Carl Ferdinand Wilhelm Walther (1811-87) i 1880 tretten teser, som her bringes i forkortet form: (1) Vi tror, lærer og bekender, at Gud har skabt alle mennesker til frelse, ingen til fortabelse, og at Han vil alle menneskers frelse. (2) Jesus døde for alle menneskers synd. (3) Gud skaber og bevarer troen ved hjælp af nådemidlerne. (4) Intet menneske går fortabt, fordi Gud ikke vil frelse ham, eller fordi Gud gik ham forbi ved sit nådevalg.

quette University 2012) http://epublications.marquette.edu/dissertations_mu/204 (besøgt 26.10.17).

19. De tidlige lutherske kirkedannelser i Nordamerika tog navn efter medlemmernes etnicitet ( $\mathrm{fx}_{\mathrm{x}}$ Norwegian Synod) eller efter kirkernes oprindelse på det nordamerikanske kontinent (fx Ohio Synod). Siden da er flere af dem, men ikke dem alle, fusioneret i Evangelical Lutheran Church of America (ELCA).

20. F.A. Schmidt, "Intuitu Fidei", The Error of Modern Missouri. Its Inception, Development, and Refutation, red. George H. Schodde, English translation by R.C.H. Lenski \& C.B. Ghodes (Columbus: Lutheran Book Concern 1897), 560-561.

21. Friedrich Schmidt, "Zeugnisse lutherischer Lehrer über die Gewissheit der Bekehrung und Erwählung”, Altes und Neues. Theologisches Zeitblatt (1880), 125. Her gengivet fra Brenner (2012), 86.

22. Schmidt (1897), 561: "To reject all consideration of the attitude of men in matters pertaining to their salvation, and then to distinguish between an antecedent and a subsequent will in reference to the subjects of salvation, would be a contradiction too plain and manifest for Missouri to father, in spite of its penchant for mysteries and contradictions." 
Man går fortabt alene på grund af sin egen synd og afvisning af Guds nåde. (5) Forudbestemmelsen er individuel. De mennesker, som Gud har forudbestemt, vil bevare troen til det sidste, eller de vil igen tro kort før deres død. (6) Udvælgelsen er uforanderlig. De udvalgte kan derfor ikke gå fortabt. (7) Det fører enten til kødelig sikkerhed eller desperation, hvis man prøver at regne ud, hvem Gud har udvalgt. (8) Vi skal opnå vished om udvælgelsen ved hjælp af Guds åbenbarede frelsesvilje. (9) Udvælgelsen er ikke sket ud fra forudset tro. Og den gælder ikke dem, der kun tror til en tid (Luk 8,23). (10) Grunden til Guds udvælgelse er alene Hans nåde og Kristi fyldestgørelse. (11) Udvælgelsen er årsag til menneskers frelse og til alt det, som er nødvendigt til frelse. (12) Gud har ikke åbenbaret alt om dette emne, så udvælgelsen er et mysterium. Vi forkaster forsøgene på at harmonisere det, som vores fornuft ikke får til at gå op. (13) Det er nødvendigt og nyttigt, at udvælgelsen forkyndes for menigheden, så langt Gud har åbenbaret dette mysterium for os. ${ }^{23}$

Paradokset eller asymmetrien ser altså sådan ud: Gud har forudbestemt de enkeltpersoner, som vil blive frelst. Men Han har ikke forudbestemt dem på baggrund af noget som helst hos dem selv, heller ikke ud fra forudset tro. Og Gud har ikke forudbestemt nogen til fortabelse. Både Missouri og Wisconsin godkendte officielt disse 13 teser.

I 1884 tilføjede Walther som svar til Friedrich Schmidt: Princippet om sola scriptura indebærer, at Bibelen er den eneste kilde for vores tro. I en lærestrid har vi ingen anden dommer end Den hellige Skrift. Selv ikke vore bekendelsesskrifter har denne autoritet. ${ }^{24}$ Bekendelsen beviser sin lære ved Bibelen, ikke ved sig selv. Hvor Bibelen lader et mysterium stå uløst, der lader vi samme mysterium stå uløst. Vi skal ikke opløse Bibelens mysterier ved at inddrage lærepunkter, der handler om noget andet. At tale i overensstemmelse med troen (Rom 12,6) betyder, ifølge Walther, at vi skal lade afsnit i Bibelen, der handler om samme emne, forklare hinanden, så vi ikke får Bibelen til at sige to helt forskellige ting om samme emne (Walther 1992, 70). Forudbestemmelse og retfærdiggørelse er to forskellige emner. Derfor

23. Her gengivet fra Moving Frontiers. Readings in the History of the Lutheran Church - Missouri Synod red. Carl S. Meyer (Saint Louis, MO: Concordia 1986), 272-273. Cf. Brenner (2012), 88-89; Thuesen (2009), 158.

24. C.F.W. Walther, Essays for the Church. Vol.2. 1877-1886, oversat af Bruce Cameron, Reinhold Stallmann \& James Ware (St. Louis, MO: Concordia 1992), 82: "There are no other judges in doctrinal controversies than the Holy Scriptures. Even the Confessions themselves, according to this, do not have this authority." Brenner (2012), 103. 
kan vi ikke sige: Fordi den ene foregår på en bestemt måde, må den anden foregå på samme måde.

I striden om Guds evige nådevalg lod Missouri og Wisconsin en asymmetri stå mellem Guds vilje til liv og Guds vilje til død. Fordi Gud er evig, er Hans vilje også evig. Men viljen til død er alligevel logisk set efter menneskers synd og vantro. Den er en voluntas consequens. Både Guds almindelige vilje til liv og Guds særlige udvælgelse til frelse er forud for og uafhængig af menneskers tro og livsførelse. I modsætning til dette gik både Norwegian og Ohio længere i forsøget på rationel forklaring af paradokset.

\section{Martin Luther. Almagt og nødvendighed}

Martin Luther tilrettelægger asymmetrien på en særegen måde, hvorved han undgår såkaldt hård determinisme. Som nævnt hævder Luther i 1520: "Alting sker med absolut nødvendighed." Det er et citat fra John Wycliffe (ca.1320-84), og det blev en del af grundlaget for den posthume fordømmelse af Wycliffe på koncilet i Konstanz i 1415. ${ }^{25} \mathrm{I}$ 1520 svarer Martin Luther på pave Leo 10.'s trussel om at bandlyse ham. Dette gør Luther altså bl.a. med et citat, som kirken allerede har fordømt. På koncilet i Konstanz blev Jan Hus (1369-1415) brændt levende som kætter på trods af frit lejde. Dette kætterbål får i 1518 følgende kommentar med på vejen fra Luther: "At brænde kættere er imod Helligåndens vilje."26 I 1521 møder Luther selv op på rigsdagen i Worms på grundlag af et frit lejde fra kejseren og på trods af vennernes advarsel om, hvordan det gik Jan Hus 106 år tidligere. At Luther citerer Wycliffe, må derfor skyldes, at Luther faktisk mener, hvad han skriver.

I 1525 genbruger han Wycliffe-citatet, men nu med en lille ændring, der formentlig har stor betydning. Luther skriver til Erasmus af Rotterdam (1466-1536): "Alting sker med nødvendighed." ${ }^{27}$ Luther skriver ikke længere absolut nødvendighed. Antagelig vil han forhindre en skolastisk misforståelse.

25. Kompendium der Glaubensbekenntnisse und kirchlichen Lehrentscheidungen. Lateinisch - Deutsch, red. Heinrich Denzinger \& Peter Hünermann (Freiburg im Breisgau: Herder 2001), 434 (\$1177).

26. Resolutiones disputationum de indulgentiarum virtute, WA 1,624,36-38: "Нaereticos et errantes concrememus ... immo contra voluntatem spiritus."

27. De servo arbitrio, WA 18,617,19: "Omnia necessitate fieri." Knut Alfsvåg, "Luther on Necessity”, HTR 108 (2015), 52-69. 
Thomas Aquinas skelner i sin Summa mellem "absolut nødvendighed" (lat. necessitas absoluta) og "betinget nødvendighed" (lat. necessitas conditionalis). ${ }^{28}$ Fordi Gud kender fremtiden i detaljer, sker alt med nødvendighed. Men noget sker med absolut nødvendighed, mens andet sker med betinget nødvendighed, hævder Thomas. Dette sidste gælder det meste af historien. Gud kender fremtiden, fordi Han så at sige står på et højdedrag og ser verdenshistorien ligge udbredt nede i dalen. Gud ser altså historien, fordi den er der. Den er der ikke, fordi Gud ser den, mener Thomas. ${ }^{29}$

Martin Luther er stærkt uenig! Han kalder Thomas og skolastikerne for sofister, som prøver at undgå konsekvenserne af Guds almagt og allestedsnærvær. Luthers skabelsesteologi er så forskellig fra deismen, som tænkes kan. I sin forelæsning over 1 Mos 2,2 i 1535 siger Luther: $\mathrm{Da}$ Gud begyndte at skabe, sendte Han sit skaberord ud. Siden da har dette skaberord frembragt både mig og alt andet. "Således løber Gud ved sit Ord fra verdens begyndelse til dens afslutning." ${ }^{30}$ Det er den almægtige og allestedsnærværende Gud selv, der ved sit skaberord fortsat virker alt i sit skaberværk. Luther ændrer ikke denne opfattelse på noget tidspunkt. Ti år tidligere skriver han: "Når det altså er Gud, der bevæger og bevirker alle ting, er det nødvendigvis også Ham, der bevæger og virker i Satan og i den ugudelige. Men Han virker i dem, som de er, og som Han forefinder dem." ${ }^{11}$ Sidste sætning i dette citat er meget vigtig! Selv om det er Guds almagt og skaberkraft, der virker alt det, som Satan og det ugudelige menneske foretager sig, så bevarer Satan og de ugudelige både vilje, spontanitet og ansvar for deres egne gerninger. Luther kalder dette et paradoks (lat. paradoxon; WA $18,634,14)$. For at kaste lys over dette paradoks skelner han mellem "tvangens nødvendighed" (lat. necessitas coactionis) og "uforanderlighedens nødvendighed" (lat. necessitas immutabilitatis). ${ }^{32}$ Den første er der tale om, når en forbryder bliver anholdt og ført til fængslet imod

28. Thomas, Summa, 1, q.19, a.8.

29. Thomas, Summa, 1, q.14, a.13; 1, q.22, a.4 og 2, q.112, a.3; Herbert Olsson, "Det dubbla necessitas-begreppet i Skolastiken och Luthers Kritik därav", Till Gustaf Aulén 15/5 1939, red. Erling Eidem et al. (Lund: Svenska Kyrkans Diakonistyrelses Bokförlag 1939), 279-310.

30. Vorlesungen über 1. Mos, WA 42,57,41-42: "Ita Deus per verbum suum currit ab initio usque ad finem mundi.” Bengt Hägglund, De homine. Människouppfattningen i äldre Luthersk tradition (Lund: Gleerup 1959), 57-58.

31. WA 18,709,21-22: "Quando ergo Deus omnia movet et agit, necessario movet etiam et agit in Satana et impio. Agit autem in illis taliter, quales illi sunt et quales invenit."

32. WA 18,634,21-23: "Necessario vero dico, non coacte, sed ut illi dicunt, necessitate immutabilitatis, non coactionis." 
sin vilje. Den anden er der tale om, når vi beslutter os for at gøre det, som vi inderst inde har mest lyst til at gøre.

Med sin tale om uforanderlighedens nødvendighed skelner Luther mellem to niveauer i menneskets vilje. Vi kunne kalde det dybeste niveau for drift eller retning og det øverste niveau for valg eller afgørelse. Ofte er vi kun bevidste om det øverste niveau i vores vilje. Vi foretager dagligt mange valg om tøj og mad og tv-programmer. Men alle disse valg er udtryk for den underliggende drift eller retning, der styrer vores personlighed. På det øverste niveau har vi en vis valgfrihed. Men vi kan ikke vælge i strid med vores drift. Vi handler aldrig i strid med selve retningen på vores personlighed. Viljens øverste niveau er trælbundet af viljens dybeste niveau. Men vi oplever os ikke trælbundet, fordi begge niveauer er udtryk for, hvem vi dybest set er, hvad vi føler, og hvad vi vil. Derfor bevæger vores valg sig med nødvendighed i den retning, som driften fører os i. Hvis vi skulle bevæge os i den modsatte retning, måtte vi tvinges til det.

Dette er for Luther ikke kun et spørgsmål om hverdagens psykologi. Synden har nemlig sat sig på viljens dybeste niveau. Synden er blevet en drift i os, en retning på vores personlighed. Derfor synder vi med nødvendighed, uanset hvad vi vælger at gøre. Men vi synder også i fuld overensstemmelse med vores inderste vilje. I én forstand synder vi altså frit, selv om det sker med nødvendighed. Vi synder med uforanderlighedens nødvendighed, men uden ydre tvang og derfor med ansvar. Skal vi ville noget andet, må Gud give os en ny vilje. Vi kan ikke gøre det selv, for vi vil det ikke. Ja, vi kan slet ikke ville det. Derfor er troens tilblivelse en dødeopvækkelse, en genfødsel, en nyskabelse. Så længe Gud ikke griber ind og gør dette under ved os, bevæger vi os spontant og med vilje, men også med nødvendighed, længere og længere bort fra Gud.

Nu presser dette spørgsmål sig på: Hvorfor gør Gud ikke det samme under ved alle mennesker?

Vi skal ifølge Luther ikke give ét, men altid to svar på dette spørgsmål: Når et menneske kommer til tro, er det Gud alene, der har gjort det. Dette er monergisme. Når et menneske hører evangeliet, men $i k k e$ kommer til tro, er det dette menneskes eget ansvar. Gud ville gerne, men dette menneske ville ikke. Det paradoksale forhold mellem Guds almagt og menneskets ansvar tilfredsstiller ikke fornuften, men vi genfinder paradokset hos Luther lige fra reformationens begyndelse til hans død.

Hvorfra kommer da den syndige vilje? Når Gud har skabt og styrer alle ting, har Han så også skabt den syndige vilje?

Nej, svarer Luther! Gud virker i Satan og i de ugudelige, "som de er, og som Han forefinder dem.” Den syndige vilje kommer fra dem selv. 
Den putter Gud ikke ind i dem. Men fordi Han er skaberkraften i alt det, der findes, og i alt det, der sker, driver Han alle menneskers og alle ånders valg og afgørelser i overensstemmelse med den drift og retning, som allerede findes i dem. Luther forklarer Erasmus: "Når det siges, at Gud forhærder eller bevirker noget ondt i os - at forhærde er jo at virke noget ondt - så gør Han ikke dette ved at skabe det onde $\mathrm{i}$ os fra nyt af (lat. de novo)." 33 Gud skaber ikke den onde drift eller retning. Den forefinder Han. Men hvor Han forefinder den, virker Han sammen med den alle dens valg og afgørelser. Disse valg virker Gud i fuld overensstemmelse med Satans og det onde menneskes eget valg. De vil ikke selv andet end det, som Gud virker i dem uimodståeligt og med uforanderlighedens nødvendighed. Gud forhærdede farao (2 Mos 4,21; 7,3 m.f.) i overensstemmelse med det hårde hjerte, som Gud fandt i farao. Denne forhærdelse er synd. Derfor virkede Gud faraos synd. Men det gjorde farao også selv. Gud virkede gennem farao, at han mishandlede israelitterne endnu mere end før (5,6ff). Men den onde kvalitet eller drift eller retning fandtes i farao i forvejen. Den leverede Gud ikke. Gud er i en vis forstand årsag til, men aldrig ansvarlig for synden.

I 2 Sam 16,7-8 bliver kong David forbandet af Shim'i. Abishaj spørger kongen, om han skal hugge hovedet af Shim'i. Men David svarer nej: "Når han forbander, er det, fordi Herren har sagt, han skal forbande mig" $(16,10)$. Luther forklarer: Guds almagt griber fat i Shim' is vilje, som er ond i forvejen, og så virker Gud forbandelsen i fuld overensstemmelse med Shim' is indre drift og retning. Shim'i gør frit og spontant det, som Gud på forhånd har besluttet, at Shim'i skal gøre (WA 18,711,10-19).

Guds almagt skaber og opretholder os uden nogen medvirken fra vores side. Gud skaber os altså de novo. Men når Han har skabt os, virker Han i, med og gennem os, så alt, hvad vi virker, også er virket af Ham, men på en sådan måde, at Han ikke sætter vores vilje, spontanitet og ansvar ud af kraft (WA 18,753-754). Guds alvirksomhed er ifølge Luther kompatibel med menneskets spontanitet og ansvar.

Hvorfra kom så det onde oprindeligt? Dette spørgsmål har Luther ikke noget svar på. Det tilhører den skjulte Gud (lat. Deus absconditus, WA 18,684-685). Guds åbenbaring er tilstrækkelig, men den er ikke udtømmende, for Gud har ikke åbenbaret alt. Det, som Gud ikke har åbenbaret, skal vi lade ligge. Som Moses siger: "De skjulte ting hører Herren vor Gud til; de åbenbare hører for evigt os og vore børn til" (5 Mos 29,28).

33. WA 18,710,31-33: "Non igitur quispiam cogitet, Deum, cum digitur indurare aut malum in nobis operari (indurare enim est malum facere), sic facere, quasi de novo in nobis malum creet." 


\section{Melanchthon mellem monergisme og synergisme}

Philipp Melanchthon delte i sine unge år fuldt ud denne opfattelse. Ja, på nogle områder udfolder han den endda med større pædagogisk klarhed end Luther; se særligt kapitlet om den frie vilje i hans Loci communes fra $1521 .^{34}$ Men ret hurtigt bliver han alligevel betænkelig. Det er formentlig Erasmus' breve og Melanchthons egen konfrontation med romerske teologer som Johann Eck (1486-1543), der får ham til at revidere sin opfattelse (Kolb 2005, 75; 85; 88). Melanchthon kom med tiden til den vurdering, at Luthers opfattelse var udtryk for stoisk fatalisme og manikæisme. ${ }^{35}$ For selv at undgå denne anklage hævder den ældre Melanchthon en evne i mennesket til at tilslutte sig nåden (lat. facultas applicandi se ad gratiam). ${ }^{36}$

Der pågår en debat om, hvorvidt eller i hvilket omfang Melanchthon eventuelt selv endte i synergisme. ${ }^{37}$ Det er ikke stedet her at afgøre dette, men hans udvikling medvirkede til den synergistiske strid, der blev bilagt midlertidigt med Konkordieformlen. Den senere ortodokse påstand om intuitu fidei er reelt - eller blev med tiden - et tilbagefald til synergismen: Et menneskes tro skyldes dels Gud og dels dette menneske selv.

Arminianismen hævder kort efter år 1600 en forekommende nåde (lat. gratia praeveniens) i alle mennesker, med hvilken Gud modvirker menneskets trælbundne vilje. Arminianerne siger: Fra Kristi kors udgår frelseskræfter til alle mennesker, som modvirker syndefordærvet og gør, at vi nu har en evne til at tilslutte os nåden. Brian Shelton har skrevet det længe savnede standardværk om Guds forekommende nåde $\mathrm{i}$ arminiansk tradition. Han erkender, at udtrykket forekom-

34. Melanchthons Werke in Auswahl Bd.2,1, red. Robert Stupperich \& Hans Engelland (Gütersloh: Bertelsmann 1952), 8-17; Corpus Reformatorum (CR) Vol.21,8693.

35. CR 9,766 \#6705: "Ich hab bei Leben Lutheri und hernach diese Stoica und Manichaea deliria verworfen, dass Luther und andre geschrieben haben.” Brev til Kurfyrst August af Sachsen d. 9. marts 1559.

36. CR 21,659: "Liberum arbitrium in homine facultatem esse applicandi se ad gratiam."

37. Oswald Bayer, "Freedom? The Anthropological Concepts in Luther and Melanchthon Compared", HTR 91 (1998), 373-387; Lowell C. Green, "The Three Causes of Conversion in Philipp Melanchthon, Martin Chemnitz, David Chytraeus, and the 'Formula of Concord', LuJ 47 (1980), 89-114; Kolb (2005), 81ff; Peter Olsen, "Alting sker med absolut nødvendighed! Om kontingens, concursus og kompatibilisme", Theofilos Supplement 6 (2014), 170-171; Timothy J. Wengert, Law and Gospel. Philip Melanchthon's Debate with John Agricola of Eisleben over Poenitentia, Text and Studies in Reformation and Post-Reformation Thought 3 (Grand Rapids, MI: Baker Books 1997); Timothy J. Wengert, "Melanchthon and Luther/Luther and Melanchthon", LuJ 66 (1999), 55-88. 
mende nåde ikke findes i Bibelen, men han konkluderer alligevel: "To move beyond the words of the biblical text and try to explain them logically is surely part of our calling as believers ... By logical abstraction, through harmonizing verses, and by 'connecting the dots,' one can easily read Scripture as describing a situation in which God enables and expects humankind to repent through his provision of prevenient grace." ${ }^{38}$ Efter Golgata er syndefordærvet en sandhed med modifikationer, for nåden begrænser dette fordærv i alle mennesker.

Denne arminianske og sidenhen metodistiske opfattelse lader til at være inspireret af luthersk synergisme omkring år 1600 - ikke mindst via den danske teologiprofessor Niels Hemmingsen (1513-1600). Der mangler dog forskning på området, så forbindelsen kan ikke fastslås med sikkerhed. Men noget tyder på, at lutherske teologer forberedte arminianismen. ${ }^{39}$

\section{Konklusion: Determinisme, kompatibilisme eller libertarianisme}

Den thomistiske skelnen mellem "absolut nødvendighed" og "betinget nødvendighed” indebærer, at Gud ikke virker det, som sker med betinget nødvendighed. Han ser det bare på forhånd og tillader det. Luthers skelnen mellem "tvangens nødvendighed" og "uforanderlighedens nødvendighed” indebærer, at Gud virker begge dele, men på to meget forskellige måder. Når Gud skaber af intet eller "fra nyt af" (lat. de novo), er der tale om tvangens nødvendighed. Når Gud virker på os med uforanderlighedens nødvendighed, bevirker Han vore spontane valg, men Han gør det i overensstemmelse med vores egen drift og vilje, så vore valg kommer inde fra os selv. Vi bliver ikke udsat for tvang (lat. coactio). Vi bliver ikke reduceret til marionetdukker eller robotter. Luthers pointe er, at den almægtige skaber af alle ting kan virke sådan på mennesker, at Han sikrer, at de frit og spontant udfører det, som Han vælger at virke gennem dem. Når vi har med den almægtige Gud at gøre, er det altså muligt, hævder Luther, at to viljer kan stå bag det, som den ene af dem frit og spontant væl-

38. W. Brian Shelton, Prevenient Grace. God's Provision for Fallen Humanity (Anderson, IN: Warner 2014), 263; 199.

39. Henrik Frandsen: Hemmingius i samme Verden som Perkinsius og Arminius. Niels Hemmingsen 1513-1600 (Præstø: Grafisk Værk 2014), 42-44; Martin Schwarz Lausten, Niels Hemmingsen. Storhed og Fald (København: Anis 2013), 302-303; Söderlund (1983), 153-159. Om forbindelsen mellem gratia praeveniens og intuitu fidei, Brenner (2012), 70; 95; 104; Schmidt (1897), 560. 
ger. Martin Luther var kompatibilist, selv om dette begreb ikke blev brugt i det 16 . århundrede.

Moderne filosofi taler om kompatibilisme, når et menneske træffer valg i en bestemt retning, dels fordi vedkommendes underliggende vilje eller drift $\mathrm{i}$ forvejen går i denne retning, og dels fordi tidligere valg og impulser har skabt denne underliggende vilje eller drift. Kompatibilismen kaldes også blød determinisme til forskel fra hård determinisme eller fatalisme. ${ }^{40}$ Mange moderne filosoffer afviser menneskets frie vilje netop med henvisning til, at vore valg er bundet indefra eller nedefra sjælens dyb og bundet af tidligere valg og impulser. Vi føler nok, at vi vælger frit. Men denne følelse skyldes, at vore valg er bundet af en dybereliggende vilje eller drift, som er udtryk for, hvem vi er inderst inde. På dette grundlag kan man godt sige, at vore valg er frie. Vi er nemlig ikke udsat for $y d r e$ tvang. Men samtidig er vore valg til stadighed bestemt af en drift, som vi aldrig selv har valgt. Vore valg har derfor med nødvendighed en bestemt retning. Begrebet kompatibilisme udtrykker, at frihed og determinisme godt kan kombineres. De er kompatible.

Den britiske filosof Bertrand Russell (1872-1970), formulerede sin egen bløde determinisme sådan: "Even if you can act as you please, you can't please as you please." 41

Andre filosoffer afviser kompatibilismen med den begrundelse, at den er spekulativ, irrationel eller nonsens..$^{42}$ Disse filosoffer argumenterer i stedet, men på ret forskellig vis, for indeterminisme eller libertarianisme, som er "den opfattelse, at mennesket har en fri vilje i kraft af hvilken det er ansvarligt for sine handlinger". ${ }^{43}$ Pointen er altså for disse filosoffer ligesom for Erasmus af Rotterdam: Et menneske kan kun holdes ansvarligt for sine handlinger, hvis disse handlinger ikke sker med nødvendighed - altså bortset fra den betingede nødvendighed, som kommer af Guds forudviden. Nogle indeterminister afviser desuden Guds forudviden om menneskers frie valg, netop fordi denne forudviden ville underlægge vore valg nødvendighed, og nødvendige valg er per definition ufrie, mener de. ${ }^{44}$

40. Kasper Lippert-Rasmussen, Viljens frihed og moralsk ansvar (København: Nyt Nordisk Forlag Arnold Busck 1999), 59-64. Se også https://plato.stanford.edu/entries/compatibilism/ (besøgt 04.01.18).

41. Galen Strawson, Freedom and Belief. Revised edition (Oxford/New York: Oxford University Press 2010), 42.

42. Karen Kilby, "Evil and the Limits of Theology", NBH 84 (2003), 13-29.

43. Politikens filosofi leksikon, red. Poul Lübcke (København: Politikens Forlag 1994), 263.

44. Peter Olsen, Open Theism on Providence and Theodicy. An Arminianized Evangelicalism (København: Københavns Universitet 2009), 294-298. 
Luthers påstand er, at Guds vilje spiller en helt anden rolle i skaberværket end et menneskes vilje. Gud kan virke i, ved og gennem vores dybeste drift på en sådan måde, at vi frit og spontant vælger noget bestemt. Dette reducerer os ikke til marionetdukker eller robotter, og det fratager os ikke ansvaret for vore valg. Valget opstår jo inde i os selv, og det er helt i overensstemmelse med vores dybeste drift. Men det er klart, at der står et paradoks eller en asymmetri tilbage: Hvordan kan Gud determinere vore valg uden at fratage os frihed og ansvar? Hvorfor determinerer Gud ikke alle menneskers tro og frelse? Hvordan kan Gud forudbestemme nogle mennesker til frelse uden dermed at forudbestemme de øvrige til fortabelse?

I modsætning til synergismen lader Martin Luther og tidlig lutherdom disse spørgsmål stå ubesvarede. 